\title{
Impact of Non-Genetic Factors on Growth Traits in Sonadi Sheep
}

\author{
Ruhi Meena*, P.C. Sharma, Sunil Khichar, Kiran Kumari bhat and Sunil Kumar Meena
}

Department of Animal Genetics and Breeding, College of Veterinary and Animal science, Navania, Vallabhnagar, Udaipur (RAJUVAS), India

*Corresponding author

\begin{tabular}{|c|c|}
\hline & A B S T R A C T \\
\hline $\begin{array}{l}\text { K e y w o r d s } \\
\text { Sonadi sheep, Non- } \\
\text { genetic factors and } \\
\text { Growth traits }\end{array}$ & $\begin{array}{l}\text { Data pertaining to } 519 \text { Sonadi sheep maintained at Mega Sheep Seed Project (Sonadi Unit) } \\
\text { College of Veterinary Science, Navania, Vallabhnagar (Rajasthan) were analyzed to } \\
\text { assess the effect of non-genetic factors (sex, season and period of lambing ) on growth } \\
\text { traits viz. birth weight (BWT), three ( } 3 \mathrm{WT}) \text {, six }(6 \mathrm{WT}) \text {, nine ( } 9 \mathrm{WT}) \text { and twelve (12WT) } \\
\text { months weights. The estimated least squares means for BWT, 3WT, 6WT, 9WT and }\end{array}$ \\
\hline Article Info & $\begin{array}{l}12 \mathrm{WT} \text { were found as } 3.07 \pm 0.03 \mathrm{~kg}, 11.32 \pm 0.30 \mathrm{~kg}, 15.94 \pm 0.56 \mathrm{~kg}, 19.12 \pm 0.53 \mathrm{~kg} \text {, } \\
22.73 \pm 0.56 \mathrm{~kg} \text {, respectively. Sex of lambing had significant influence on all growth traits. }\end{array}$ \\
\hline $\begin{array}{l}\text { Accepted: } \\
\text { 10 March } 2019 \\
\text { Available Online: } \\
10 \text { April } 2019\end{array}$ & $\begin{array}{l}\text { Higher estimates were observed in males as compared to females for all the traits studied. } \\
\text { Season had significant influence on birth weight }(\mathrm{P}<0.01) \text { and weight at six months } \\
(\mathrm{P}<0.05) \text {. In general, the lambs born in monsoon season were found heavier than those } \\
\text { born in winter season. The effect of period was significant on all body weight except birth } \\
\text { weight and weight at } 12 \text { month }(12 \mathrm{WT}) \text {. }\end{array}$ \\
\hline
\end{tabular}

\section{Introduction}

Sonadi sheep has the unique characteristics of survival on scarce fodder condition during drought and to produce golden fiber. Sonadi rams are not available in optimum number in the breeding tract due to cross breeding with Marwari sheep. Profitability is important component in small ruminant production system that is influenced by growth and reproduction performance traits. Growth performance is an important indicator for profitability as fast growth rate entails reaching market weight early, which brings a quicker income to the farmer. It also has implication in the reproductive efficiency of individual. Fast growth performance allows individual to breed early and contribute more progeny in its lifetime (Momoh et al., 2013). Lambs weighed more and grew faster than kids, irrespective of the stage of growth. Thereby, the growth potential of the lambs is very important in the sheep production. It is essential to have knowledge of genetic parameters for these economically important traits to formulate optimum breeding strategies for better production. Growth traits are influenced by direct additive genetic effect. Keeping in view the above economic consequences of growth traits, the present investigation was planned to estimate the effect of non-genetic factors on animal productivity in sonadi sheep. 


\section{Materials and Methods}

Data on growth at birth (BWT), 3(3WT), 6(6WT), 9(WT), 12(WT) were collected from 519 animals belongs to 258 females and 261 males spread over a period of 4 years from 2014 to 2017 maintained at Mega Sheep Seed Project Coordinating Sonadi sheep unit, CVAS Navania. On the basis of year, data was categorized into four categories and coded from 1-4 for the corresponding year. The data related to gender of lamb was classified according to male and female and coded as 1 for male and 2 for female. On the basis of prevailing lambing pattern, lambing seasons was categorized into two seasons as Major (November to December) and Minor (July to October) lambing season. The influence of season, period and sex on growth traits were studied by least squares analysis. All animal in this flock were kept in semi intensive management system. Grazing is regular phenomenon of this flock and minimum 8 hours grazing was provided in addition to $300 \mathrm{gm}$ concentrates per head per day.

Since the subclass numbers were unequal and disproportionate, the data were analysed by the least squares procedure of fitting constants using LSMLMW programme (Harvey, 1990). The model used for analysis was as follows:

$\mathrm{Y}_{\mathrm{ijkl}}=\mu+\mathrm{P}_{\mathrm{i}}+\mathrm{S}_{\mathrm{j}}+\mathrm{S}_{\mathrm{xk}}+\mathrm{e}_{\mathrm{ijkl}}$

Where,

$\mathrm{Y}_{\mathrm{ijkl}}=$ Observation of $\mathrm{t}^{\text {th }}$ record of $\mathrm{k}^{\text {th }}$ sex, $\mathrm{j}^{\text {th }}$ season, $i^{\text {th }}$ period

$\mu=$ Overall mean

$P_{i}=$ Effect of $i^{\text {th }}$ period of birth $(i=1,2,3,4)$

$S_{j}=$ Effect of $j^{\text {th }}$ season of birth $(j=1,2)$

$\mathrm{S}_{\mathrm{xk}}=$ Effect of $\mathrm{k}^{\text {th }}$ sex of individual $(\mathrm{k}=1,2)$

$\mathrm{e}_{\mathrm{ijk} 1}=$ Random error associated with each observed $Y_{\mathrm{ijk}}$ and assumed to be $\operatorname{NID}\left(0,{ }^{\sigma 2}\right)$

\section{Results and Discussion}

The overall least squares means along with standard error of body weight were observed as $3.07 \pm 0.20,11.32 \pm 0.16,16.42 \pm 0.18$, $19.46 \pm 0.20$ and $23.23 \pm 0.40 \mathrm{~kg}$ at birth, 3 , 6,9 and 12 months of age as shown in the table 1 . The estimate of birth weight was slightly lower in comparison to the findings of Mallick et al., (2015) which was $3.65 \pm 0.06$ $\mathrm{kg}$ in crossbred sheep.

\section{Season of lambing}

Lambs born during monsoon season achieved higher growth rate and feed conversion efficiency. Season had significant $(\mathrm{P}<0.01)$ influence on birth weight and did not show any significant $(\mathrm{P}<0.05)$ effect on post weaning growth traits except six months body weight. In general, the lambs born in monsoon season were found heavier than those born in winter season. In minor season lambing, the values for growth traits were high due to improved nutritional status that provide better uterine environment to the fetus and manifested in birth weight of July to October born lambs. Significant effect on birth weight of lamb was also reported by Sharma et al., (2016) in Sonadi sheep, Gowane et al., (2015) in Malpura sheep and Nirban et al., (2015) in Marwari sheep.

\section{Period of lambing}

The effect of period was significant on all body weight except birth weight and weight at 12 months (12WT). Most of growth traits were found to increase in late period compared to early period. Period of lambing showed an increasing trend over the period for weight at 9 months of age. The influence of period on body weight could be the result of changes in environmental factors. The increase in body weight over the period may be due to improvement in management practices. 
Table.1 Season, period and sex-wise least squares means with standard errors of growth traits of Sonadi sheep

\begin{tabular}{|c|c|c|c|c|c|}
\hline Effect & BWT & 3WT & $6 \mathrm{WT}$ & 9WT & 12WT \\
\hline $\mathbf{N}$ & 519 & 373 & 257 & 179 & 145 \\
\hline $\boldsymbol{\mu}$ & $3.07 \pm 0.02$ & $11.32 \pm 0.19$ & $16.42 \pm 0.25$ & $19.46 \pm 0.34$ & $23.23 \pm 0.40$ \\
\hline Season & $* * *$ & NS & $*$ & NS & NS \\
\hline Season I & $\begin{array}{c}3.01 \pm 0.03 \\
(306)\end{array}$ & $\begin{array}{c}11.23 \pm 0.30 \\
(207)\end{array}$ & $\begin{array}{c}15.94 \pm 0.56 \\
(123)\end{array}$ & $\begin{array}{c}19.12 \pm 0.53 \\
(94)\end{array}$ & $\begin{array}{c}22.73 \pm 0.56 \\
(82)\end{array}$ \\
\hline Season II & $\begin{array}{c}3.13 \pm 0.04 \\
\quad(213)\end{array}$ & $\begin{array}{c}11.41 \pm 0.33 \\
(166)\end{array}$ & $\begin{array}{c}16.89 \pm 0.40 \\
(134)\end{array}$ & $\begin{array}{c}19.80 \pm 0.57 \\
(85)\end{array}$ & $\begin{array}{c}23.73 \pm 0.64 \\
(63)\end{array}$ \\
\hline Period & NS & $* * *$ & $* * *$ & $* * *$ & NS \\
\hline I & $\begin{array}{c}3.01 \pm 0.03 \\
(187)\end{array}$ & $\begin{array}{l}6.73 \pm 0.25 \\
(106)\end{array}$ & $\begin{array}{c}12.82 \pm 0.36 \\
(90)\end{array}$ & $\begin{array}{c}17.78 \pm 0.43 \\
(84)\end{array}$ & $\begin{array}{c}23.23 \pm 0.49 \\
\text { (73) }\end{array}$ \\
\hline II & $\begin{array}{c}3.11 \pm 0.03 \\
(162)\end{array}$ & $\begin{array}{c}12.37 \pm 0.22 \\
(138)\end{array}$ & $\begin{array}{c}17.30 \pm 0.35 \\
(94)\end{array}$ & $\begin{array}{c}19.46 \pm 0.45 \\
(73)\end{array}$ & $\begin{array}{c}22.57 \pm 0.49 \\
\text { (69) }\end{array}$ \\
\hline III & $\begin{array}{c}3.10 \pm 0.03 \\
(155)\end{array}$ & $\begin{array}{c}11.74 \pm 0.23 \\
(123)\end{array}$ & $\begin{array}{c}16.42 \pm 0.43 \\
(73)\end{array}$ & $\begin{array}{c}23.10 \pm 0.87 \\
(22)\end{array}$ & $\begin{array}{c}24.59 \pm 2.39 \\
\text { (3) }\end{array}$ \\
\hline IV & $\begin{array}{c}3.06 \pm 0.11 \\
(15)\end{array}$ & $\begin{array}{c}14.43 \pm 1.06 \\
(6)\end{array}$ & & & \\
\hline Sex & $* * *$ & $* * *$ & $* * *$ & $* * *$ & $* * *$ \\
\hline I & $\begin{array}{c}3.13 \pm 0.03 \\
(261)\end{array}$ & $\begin{array}{l}11.72 \pm 0.31 \\
(187)\end{array}$ & $\begin{array}{l}17.24 \pm 0.48 \\
\text { (122) }\end{array}$ & $\begin{array}{c}21.07 \pm 0.54 \\
(83)\end{array}$ & $\begin{array}{c}25.72 \pm 0.64 \\
(65)\end{array}$ \\
\hline II & $\begin{array}{c}3.01 \pm 0.03 \\
(258)\end{array}$ & $\begin{array}{c}10.91 \pm 0.32 \\
(186)\end{array}$ & $\begin{array}{l}15.59 \pm 0.48 \\
(135)\end{array}$ & $\begin{array}{c}17.85 \pm 0.54 \\
(96)\end{array}$ & $\begin{array}{c}20.74 \pm 0.56 \\
(80)\end{array}$ \\
\hline
\end{tabular}

BWT $=$ Birth weight; 3WT= 3-month weight; $6 \mathrm{WT}=6$-month weight, 9WT=9-month weight; 12WT= 12-month weight; $* \mathrm{P}<0.05 ; * * \mathrm{P}<0.01 * * * \mathrm{P}<0.001$

\section{Sex of lamb}

The sex of lamb showed significant effect $(\mathrm{P}<0.001)$ on all growth traits. Higher estimates were observed in males as compared to females. It is general tendency that male lambs had a higher weight and grew faster than females. The significant effect of sex on all growth traits of lambs were also reported by Sharma et al., (2016) in Sonadi sheep. These sex differences are consistent with results from other investigations in various breeds (Thiruvenkadam et al., 2011; Siddalingamurthy et al., 2017). The difference between both the sexes can be due to the hormonal differences in their endocrinological and physiological functions.

\section{Acknowledgement}

The author thanks to head of Mega Sheep Seed Project coordinating Sonadi sheep unit, CVAS Navania, Udaipur for providing help during sample and data collection and for providing me all the necessary facilities to conduct the research.

\section{References}

Gowane, G. R., Prince, L.L.L., Lopes, F. B.; Paswan, C. and Sharma, R.C. 2015. Genetic and phenotypic parameters estimates of live weight and daily gain traits in Malpura sheep using Bayesian approach in Malpura.

Harvey, W.R. (1990). User's guide for 
LSMLMW PC-1 version; mixed model least squares and maximum likelihood computer programme. Mimeograph Ohio State Univ., USA.

Mallick, P.K, pourouchottamane, R., Rajapandi, S., Thirumaran, S. M. K. and Rajendrian A. S. 2015. Performance of Bharat merino $x$ Bannur (Mandya) crossbreds in kolar and chikballpur districts of Karnataka. The indian journal of small ruminant, 21(1): 28-31.

Momoh, O. M., Rotimi, E. A. and Dim, N. I. 2013. Breed effect and non-genetic factors affecting growth performance of sheep in semi-arid region of Nigeria. Journal of applied biosciences, 67: 5302-5307.

Nirban, L. K., Joshi, R. K. ～Narula, H. K.; Singh, H. and Bhakar, S. 2015. Estimates of heritability for growth and wool traits in Marwari sheep at arid region of Rajasthan. Indian
Journal of Animal Research, 49(6): 872-874.

Sharma, P. C., Gupta, Barkha, Joshi, Monika, Preet, Tarun; Pareek, S., Rathore, N. S. and Nagda, R. K. 2016. Influence of genetic and non- genetic factors on growth performance of sonadi sheep. Ruminant science, 5(2): 165-167.

Siddalingamurthy, H. K., Manju, G.U., Roopa Devi, Y.S., Manjunatha, S. S. and Sreesujatha, R. M. 2017. Non-genetic factors affecting birth and weaning weight in mandya sheep. Int. J. Adv. Res., 5(4): 345-348.

Thiruvenkadan, A. K., Karunanithi, K., Muralidharan, J. and Babu, R. N. 2011. Genetic analysis of pre-weaning and post-weaning growth traits of Mecheri sheep under dry land farming conditions. Asian-Aust. J. Anim. Sci., 24: $1041-1047$.

\section{How to cite this article:}

Ruhi Meena, P.C. Sharma, Sunil Khichar, Kiran Kumari bhat and Sunil Kumar Meena. 2019. Impact of Non-Genetic Factors on Growth Traits in Sonadi Sheep. Int.J.Curr.Microbiol.App.Sci. 8(04): 1289-1292. doi: https://doi.org/10.20546/ijcmas.2019.804.148 